\title{
Post-ruminal or intravenous infusions of carbohydrates or amino acids to dairy cows 2 . Late lactation
}

\author{
I. Schei ${ }^{1,2}$, A. Danfær ${ }^{3}$, L. T. Mydland ${ }^{1}$ and H. Volden ${ }^{1 \dagger}$ \\ ${ }^{1}$ Department of Animal and Aquacultural Sciences, Norwegian University of Life Sciences, PO Box 5003, N-1432Ås, Norway; ${ }^{2}$ TINE BA, PO Box 58, N-1430Ås, \\ Norway; ${ }^{3}$ Danish Institute of Agricultural Sciences, Research Centre Foulum, PO Box 50, DK-8830 Tjele, Denmark
}

(Received 11 March 2006; Accepted 11 December 2006)

The objectives of this study were to compare the effects of post-ruminal and intravenous infusions of wheat starch or glucose $(\mathrm{CHO})$ or a mixture of amino acids $(A A)$ on milk protein yield, nitrogen $(N)$ utilisation, plasma metabolites and mammary extraction rate of dairy cows in late lactation. Eight cow, ruminally fistulated, was assigned to two $4 \times 4$ Latin squares during 14-day periods, where the last 7 days were for infusions. Infusions were: (1) starch in the abomasum (SP), (2) glucose in the blood (GB), (3) $A A$ in the abomasum (AP), and (4) $A A$ in the blood (AB). The experiment started $165 \pm 4$ days (mean \pm s.e.) post partum (milk yield $22.5 \pm 1.1 \mathrm{~kg}$ ) Daily amounts of nutrients infused were 257, 283, 233, and $260 \mathrm{~g}$ for $S P, G B, A P$ and $A B$, respectively. The cows were fed a basal diet consisting of a concentrate mixture and grass silage (55:45 on a dry-matter (DM) basis), where total dry-matter intake (DMI) was $13.3 \mathrm{~kg} /$ day. Milk production was affected by site of infusion within substrate, whereas infusion substrates within infusion site (CHO or $A A$ ) were of minor importance. Responses to intravenous infusions (GB or $A B$ ) were similar to those in early lactation, but more pronounced. Compared with SP infusion, GB infusion increased $(\mathrm{P}<0.05)$ milk yield, energy-corrected milk $(E C M)$, protein and lactose yield by 1.4 and $0.9 \mathrm{~kg}$, 38 and $59 \mathrm{~g}$, respectively. The $A B$ infusion had 1.4 and $1.3 \mathrm{~kg}, 51,52$ and $50 \mathrm{~g}$ higher $(\mathrm{P}<0.05)$ milk yield, ECM, protein, fat and lactose yields than the $A P$ infusion, respectively. $N$ balance data indicated higher losses of metabolic faecal nitrogen (MFN) by abomasal than by intravenous infusions, but the catabolism of $A A$ was lower than in early lactation indicated by no difference $(\mathrm{P}<0.05)$ in urinary $N$ excretion between treatments. Intravenous AA infusion increased plasma glucose and insulin above that of intravenous glucose infusion. The treatment effects on plasma insulin concentrations were higher in late than in early lactation, suggesting a higher sensitivity in late lactation even at similar negative energy balance. Compared with the SP infusion, GB infusion showed lower $(\mathrm{P}<0.05)$ concentrations of essential $A A(E A A)$ and branched-chain $A A(B C A A)$ resulting in a higher $A A$ utilisation because of a higher milk protein production. $A P$ infusion increased $(P<0.05)$ plasma non-essential $A A$ concentration compared with $A B$ infusion, but infusion site of $A A$ had no effect $(\mathrm{P}>0.05)$ on plasma EAA or $B C A A$. It is concluded that it is the nutrient supply and not the lactation stage per se that is important for the response in milk production. Nevertheless, stage of lactation affects the $N$ metabolism and the response in plasma hormone concentrations even when cows are in negative energy balance in both lactation stages.

Keywords: amino acid infusion, dairy cows, glucose, late lactation

\section{Introduction}

Milk protein response to supplemental metabolizable amino acids (AA) depends on stage of lactation (Aikman et al., 2002). However, it is not clear if this is a lactation stage effect per se or an interaction with animal energy status. Therefore, we wanted to compare directly, within the same animals and similar energy balance at two lactation stages, the effect of abomasal or intravenous carbohydrate

\footnotetext{
${ }^{\dagger}$ E-mail: harald.volden@umb.no
}

$(\mathrm{CHO})$ or AA delivery on milk production response, nitrogen (N) utilisation and plasma metabolites. In our accompanying paper (Schei et al., 2007), we presented the responses obtained in early lactation starting $54( \pm 4)$ days post partum. In this paper we will present a replicate of the experiment using the same animals and the same basal diet in late lactation, starting $165( \pm 4)$ days post partum. The objectives of this study were to evaluate multiple comparisons of starch, glucose or AA infused in the abomasum or intravenously on production responses, $\mathrm{N}$ utilisation and plasma metabolites in late lactation. The experimental 
comparisons were: (1) abomasal starch versus intravenous glucose infusion, (2) abomasal versus intravenous AA infusion, (3) abomasal starch versus AA infusion, and (4) intravenous glucose versus AA infusion. The early lactation study was conducted with animals in negative energy balance and therefore same energy balance was used in late lactation. Similar energy balances were important since it may have effects on milk responses (Hanigan et al., 1998; Schei et al., 2005) and also makes it more comparable with early lactation responses.

\section{Material and methods}

\section{Animals and basal diets}

Eight Norwegian Red cows fitted with ruminal cannulae were used. The cows were the same as used in the early lactation experiment presented in our accompanying paper (Schei et al., 2007). The experiment was conducted in late lactation starting $165 \pm 4$ (mean \pm s.e.) days post partum (milk yield $22.5 \pm 1.1 \mathrm{~kg}$ ). The cows were fed the same basal ration consisting of concentrate and grass silage in the same ratio $55: 45$ and using the same feeding management as in the early lactation experiment (Schei et al., 2007). Silage was stored in tower silos until start of the early lactation experiment, then packed in plastic bags and frozen until use also for the late lactation trial, to ensure that the same feed was used in both lactation stages. In the period between the early and late lactation experiment, the cows were fed ad libitium silage and one week before the first infusion period, dry matter (DM) feed allowance was reduced to the experimental level, restricted to $95 \%$ of pre-experimental net energy (NEL) requirements. For all cows, daily DM intake (DMI) was set to $7 \mathrm{~kg}$ concentrate DM and $6.3 \mathrm{~kg}$ silage DM. Ingredients and chemical composition of the basal diet are presented by Schei et al. (2007).

\section{Experimental procedures and treatments}

This experiment was replicate of the early lactation experiment and has thoroughly been described by Schei et al. (2007). Two $4 \times 4$ Latin squares were designed with the following treatments: (1) starch in the abomasum (SP), (2) glucose in the blood (GB), (3) amino acids in the abomasum (AP), and (4) amino acids in the blood (AB). Pure wheat starch (Tritici amylum) and glucosum anhydricum were used as starch and glucose supplements. The amino acid mixture contained 16 L-amino acids with an overall composition as presented by Schei et al. (2007) but daily infusion of starch, glucose and AA were reduced to 300 , 335 and $300 \mathrm{~g}$, respectively, corresponding to $23 \mathrm{~g}$ of infusion per $\mathrm{kg} \mathrm{DMI}$. The procedures for the infusion management and the infusion rates were equal as in the early lactation stage experiments (Schei et al., 2007). Because some AA were precipitated after freezing and heavily dissolved, the procedures for preparing the AA were changed in the late stage of lactation. Therefore, the AA solutions were not frozen, but prepared daily. When dissolved in 81 of ultra-purified sterile pyrogen-free water, $\mathrm{pH}$ was adjusted and then the solution was sterilised through the vacuum filters into sterile bottles ready for use.

Measurements, sample collection and analytical procedures Measurements, sample collection and analytical procedures have been described by Schei et al. (2007).

\section{Animal care}

All cows were cared for according to laws and regulations controlling experiments in live animals in Norway (i.e. the Animal Protection Act of 20 December, 1974, and the Animal Protection Ordinance Concerning Experiments in Animals of 15 January, 1996).

\section{Calculations and statistical analysis}

All calculations have been described by Schei et al. (2007). Data used in the statistical analyses were averages from the last $3 d$ of each treatment period. The effects of treatment on feed intake, digestibility, milk yield, milk chemical production and composition, $\mathrm{N}$ balances and plasma metabolites were run using the same statistical model with the MIXED procedure of Statistical Analysis Systems Institute (1999) as presented in our corresponding paper (Schei et al., 2007). The model was tested for residual effects, but no effect was detected, and it was therefore removed from the model. Results are presented as least square means with standard error of the mean (s.e.). Pdiff-statement was used to identify significant differences between means. Differences were considered statistically significant when $P \leq 0.05$, and trends were considered to exist when $0.05<P \leq 0.10$.

\section{Results}

Feed intake and total tract digestibility Infusion levels, feed intake and total tract digestibility of organic matter (OM) and crude protein $(\mathrm{CP})$ are presented in Table 1. The amount of substrates infused was lower than planned and this affected the calculated nutrient supply. Total metabolisable energy (ME) intake was lower $(P<0.05)$ in the SP infusion compared with the other treatments because of a lower CP digestibility. As planned, total $C P$ intake was higher in $A P$ and $A B$ infusions than in $\mathrm{SP}$ and $\mathrm{GB}$ infusions, on average $237 \mathrm{~g}$ higher. The $\mathrm{OM}$ digestibility was higher on AP infusion than on the SP and $\mathrm{GB}$ infusions. The digestibility of CP was, on average, 3.6\% units lower $(P<0.05)$ when starch was infused than when the other nutrients were infusions. Calculated energy balances showed that the cows were underfed by, on average, 11.8 MJ NEL. Higher $(P<0.05)$ energy balance was observed for the AP infusion than for the other treatments, mainly because of a higher OM digestibility.

\section{Milk yield, composition and efficiency}

Milk yield, milk composition and milk efficiency are presented in Table 2. In general, the production responses 
Table 1 Means of daily intake and digestibility of nutrients by dairy cattle infused with carbohydrates or amino acids into the abomasum or blood in late lactation

\begin{tabular}{|c|c|c|c|c|c|c|}
\hline & \multicolumn{6}{|c|}{ Treatments $^{\dagger}$} \\
\hline & SP & GB & AP & $A B$ & s.e. & Significance \\
\hline Infusion (g) & $257^{\mathrm{k}}$ & $283^{j}$ & $233^{1}$ & $260^{k}$ & 6.2 & $* * *$ \\
\hline \multicolumn{7}{|l|}{ Intake (kg dry matter) } \\
\hline Total & 13.3 & 13.3 & 13.2 & 13.2 & 0.23 & \\
\hline Concentrate & 7.0 & 7.0 & 7.0 & 7.0 & - & - \\
\hline Silage & 6.3 & 6.3 & 6.2 & 6.2 & 0.22 & \\
\hline Crude protein $^{\ddagger}$ & $2.092^{\mathrm{k}}$ & $2.095^{\mathrm{k}}$ & $2.320^{\mathrm{j}}$ & $2.341^{j}$ & 0.0321 & $* * *$ \\
\hline Starch $^{\ddagger}$ & $3.385^{\mathrm{j}}$ & $3.128^{k}$ & $3.128^{k}$ & $3.128^{k}$ & 0.0046 & $* * *$ \\
\hline Metabolisable energy (MJ) & $134^{\mathrm{k}}$ & $137^{\mathrm{j}}$ & $137^{\mathrm{j}}$ & $138^{j}$ & 2.4 & $\|$ \\
\hline Energy balance ${ }^{\S}(\%)$ & $-16.5^{j}$ & $-17.2^{j}$ & $-12.6^{k}$ & $-17.7^{j}$ & 4.14 & * \\
\hline \multicolumn{7}{|l|}{ Digestibility } \\
\hline Organic matter (\%) & $70.2^{\mathrm{k}}$ & $70.7^{\mathrm{k}}$ & $72.1^{\mathrm{j}}$ & $71.2^{\mathrm{jk}}$ & 0.52 & * \\
\hline Crude protein (\%) & $67.9^{k}$ & $70.9^{\mathrm{j}}$ & $72.4^{j}$ & $71.3^{\mathrm{j}}$ & 0.72 & ** \\
\hline
\end{tabular}

${ }_{\mathrm{j}, \mathrm{k}, \mathrm{l}}$ Means within the same row and lactation stage with different superscripts differ $(P<0.05)$.

${ }^{\dagger}$ Treatments; $\mathrm{SP}=$ starch infused in abomasum; $\mathrm{GB}=$ glucose infused in blood; $\mathrm{AP}=$ amino acids infused in abomasum; $A B=$ amino acids infused in blood.

${ }^{\ddagger}$ Included infused solutions.

$\S 100 \times[($ ME intake - ME maintenance $) \times 0.67-$ milk NEL $] /$ milk NEL.

"Approaching significant $(P<0.10)$.

were highly affected by infusion site (abomasal versus blood; measured as individual treatment comparisons), whereas infusion substrates ( $\mathrm{CHO} v$ v. AA; measured as individual treatment comparisons) were of minor importance. Treatments differed $(P<0.05)$ for all variables except milk composition (protein, fat and lactose concentrations) which tended to differ $(P<0.10)$. The $\mathrm{GB}$ and $A B$ infusions were higher $(P<0.05)$ in milk yield, energy corrected milk, protein and lactose yields than the SP and AP infusions, in average, 1.4 and $1.1 \mathrm{~kg}, 45$ and $55 \mathrm{~g}$ higher, respectively. Moreover, milk fat yield was $52 \mathrm{~g}$ higher $(P<0.05)$ on $A B$ treatment compared with the AP treatment. The GB tended to $(P<0.10)$ be lower in milk fat concentration than the other treatments, and also tended to have lower $(P<0.10)$ protein concentration compared with the $A B$ infusion. The ME efficiency for milk production was lower $(P<0.05)$ for the AP infusion than for the other treatments. No differences $(P>0.05)$ were found between $G B$ and $A B$ infusions, or between SP and AP infusion except in lactose concentration which tended to differ $(P<0.10)$ between treatments.

Table 2 Means of daily milk yield, milk composition and energy efficiency by dairy cattle infused with carbohydrates or amino acids into the abomasum or blood in late lactation

\begin{tabular}{|c|c|c|c|c|c|c|}
\hline & \multicolumn{6}{|c|}{ Treatments $^{\dagger}$} \\
\hline & SP & GB & AP & $A B$ & s.e. & Significance \\
\hline \multicolumn{7}{|l|}{ Yield } \\
\hline Milk (kg) & $21.3^{\mathrm{k}}$ & $22.7^{\mathrm{j}}$ & $21.2^{\mathrm{k}}$ & $22.6^{j}$ & 1.16 & ** \\
\hline $\mathrm{ECM}^{\ddagger}(\mathrm{kg})$ & $20.6^{k}$ & $21.5^{\mathrm{j}}$ & $20.6^{k}$ & $21.9^{\mathrm{j}}$ & 1.28 & ** \\
\hline Protein $(\mathrm{g})$ & $651^{\prime}$ & $689^{\mathrm{jk}}$ & $657^{\mathrm{kl}}$ & $708^{j}$ & 34.4 & * \\
\hline Fat $(g)$ & $822^{k}$ & $847^{\mathrm{jk}}$ & $822^{k}$ & $874^{\mathrm{j}}$ & 59.5 & ** \\
\hline Lactose (g) & $1004^{\mathrm{k}}$ & $1063^{j}$ & $995^{\mathrm{k}}$ & $1045^{j}$ & 60.3 & ** \\
\hline \multicolumn{7}{|l|}{ Milk composition (g/kg) } \\
\hline Protein & 30.6 & 30.5 & 31.1 & 31.4 & 0.63 & $\|$ \\
\hline Fat & 38.4 & 37.3 & 38.7 & 38.5 & 1.53 & $\|$ \\
\hline Lactose & 47.0 & 46.8 & 46.8 & 46.3 & 0.73 & $\|$ \\
\hline Milk energy (MJ) & $64.3^{\mathrm{k}}$ & $67.2^{\mathrm{j}}$ & $64.3^{\mathrm{k}}$ & $68.3^{\mathrm{j}}$ & 3.99 & ** \\
\hline Energy efficiency $\left.{ }^{\S} \%\right)$ & $81.8^{\mathrm{j}}$ & $82.5^{\mathrm{j}}$ & $78.8^{k}$ & $82.6^{\mathrm{j}}$ & 3.43 & * \\
\hline
\end{tabular}

$\overline{j, k, l}$ Means within the same row and lactation stage with different superscripts differ $(P<0.05)$.

${ }^{\dagger}$ Treatments; $\mathrm{SP}=$ starch infused in abomasum; $\mathrm{GB}=$ glucose infused in blood; $\mathrm{AP}=$ amino acids infused in abomasum; $\mathrm{AB}=$ amino acids infused in blood.

${ }^{\ddagger}$ Energy-corrected milk.

$\S 100 \times$ milk energy/(ME intake - ME maintenance).

"Approaching significance $(P<0.10)$. 
Schei, Danfær, Mydland and Volden

\section{$N$ balance}

The $\mathrm{N}$ balance data are presented in Table 3. The $\mathrm{N}$ intake was in accordance with dietary CP intake and infusion treatments. The SP and AP infusion had 11 and $8 \mathrm{~g} /$ day higher $(P<0.05)$ faecal $N$ losses by than the $G B$ and $A B$ infusion, respectively. In percentage of $\mathrm{N}$ intake, the $\mathrm{SP}$ infusion had $3 \%$ units higher $(P<0.05)$ faecal $N$ loss compared with the GB infusion. The corresponding difference between the $A P$ and $A B$ treatments were $2.1 \%$ unit higher $(P<0.05)$ in $A P$ than in $A B$ infusion. In percentage of $\mathrm{N}$ intake, the SP infusion showed $4.5 \%$-units higher $(P<0.05)$ faecal $N$ loss than the AP infusion, and the GB infusion was $3.6 \%$ units higher than the $A B$ infusion. No difference was found between treatments in urinary $\mathrm{N}$ excretion measured either as g/day or in \% of $\mathrm{N}$ intake. When $\mathrm{N}$ secretion in milk was calculated as a proportion of total $\mathrm{N}$ intake, the GB infusion had the highest and AP the lowest $\mathrm{N}$ output. The $\mathrm{N}$ balance was lower $(P<0.05)$ for $S P$ infusion than for $A P$ and $A B$ infusions. All treatments differed $(P<0.05)$ from each other in plasma urea concentration and the lowest values were found in the SP treatment and the highest for the $A B$ infusion.

\section{Plasma metabolites}

Plasma metabolites, hormones and mammary extraction rates of plasma metabolites are presented in Tables 4, 5 and 6 . Infusion of glucose into the blood by $283 \mathrm{~g}$ daily in late lactation did not increase $(P<0.05)$ plasma glucose or insulin concentrations above that of the other treatments (Table 4). However, the AB infusion had higher $(P<0.05)$ plasma concentration of both glucose and insulin than the other treatments. Plasma non-esterified fatty acid (NEFA) concentrations were higher $(P<0.05)$ on treatment $A P$ and $A B$ than on treatment $S P$ and $G B$. The extraction rates of glucose and NEFA were not affected $(P>0.10)$ by treatments (Table 4). The GB infusion increased IGF-1 concentration compared with the other treatments. BGH tended to differ $(P<0.10)$ between treatments, whereas glucagon was unaffected $(P>0.10)$. The plasma level of total AA (TAA) was not affected $(P>0.10)$ by treatments, but essential AA (EAA), non-essential AA (NEAA) and branched-chain AA (BCAA) differed $(P<0.05)$ between treatments. Compared with the $S P$ and $G B$ infusions, the $A B$ and $A P$ infusions had higher $(P<0.05)$ plasma concentrations of EAA and $B C A A$, and the plasma concentrations of EAA and BCAA were lower $(P<0.05)$ on the GB infusion than on the SP infusion. The plasma NEAA concentration was lower $(P<0.05)$ for $A B$ infusion compared with the other treatments. Of the individual EAA, His, Leu and Val were higher $(P<0.05)$ on treatments $A P$ and $A B$, lle, Leu and Val was lower $(P<0.05)$ on treatment $G B$, and Lys was higher $(P<0.05)$ on treatment AP compared with the other treatments. The most important effects on the NEAA were the lower $(P<0.05)$ plasma Ala concentration on the $A B$ infusion and higher $(P<0.05)$ Gln and Ser concentration on the $G B$ treatment compared with the other treatments. The mammary extraction rates of the TAA, EAA and NEAA were not affected $(P<0.05)$ by treatments, but the extraction rate of the BCAA was higher on the GB infusion than on the other treatments. Of the individual $A A$, extraction rate of His was lower by the $A B$ infusion than for SP and GB infusion, and extraction rates of Ile and Leu also differed $(P<0.05)$ between treatments. For these $A A$, lowest extraction rate was observed on the AP treatment and highest on the $A B$ and $G B$ treatments.

\section{Discussion}

Nutritional responses on milk production are related to the animal physiological state, which is dependent on stage of

Table 3 Means of daily nitrogen (N) intake and utilisation, plasma urea and faecal nucleic acid bases by dairy cattle infused with carbohydrates or amino acids into the abomasum or blood in late lactation

\begin{tabular}{|c|c|c|c|c|c|c|}
\hline & \multicolumn{6}{|c|}{ Treatments $^{\dagger}$} \\
\hline & SP & GB & AP & $A B$ & s.e. & Significance \\
\hline $\mathrm{N}$ intake $(\mathrm{g})$ & $335^{k}$ & $335^{\mathrm{k}}$ & $371^{j}$ & $375^{\mathrm{j}}$ & 5.1 & $* * *$ \\
\hline \multicolumn{7}{|l|}{ N output (g) } \\
\hline Faeces & $108^{j}$ & $97^{\mathrm{kl}}$ & $103^{\mathrm{jk}}$ & $95^{1}$ & 3.0 & * \\
\hline Urine & 116 & 110 & 126 & 123 & 6.9 & \\
\hline Milk & $102^{\prime}$ & $108^{\mathrm{jk}}$ & $103^{\mathrm{kl}}$ & $111^{j}$ & 5.4 & * \\
\hline Balance & $9^{k}$ & $20^{\mathrm{jk}}$ & $39^{j}$ & $45^{\mathrm{j}}$ & 8.4 & * \\
\hline Plasma urea (mmol/l) & $3.56^{\mathrm{m}}$ & $4.22^{1}$ & $5.07^{k}$ & $5.50^{\mathrm{j}}$ & 0.14 & $* * *$ \\
\hline \multicolumn{7}{|l|}{$\mathrm{N}$ output ( $\%$ of intake) } \\
\hline Faeces & $32.1^{j}$ & $29.1^{\mathrm{k}}$ & $27.6^{\mathrm{k}}$ & $25.5^{1}$ & 0.69 & $* * *$ \\
\hline Urine & 34.5 & 32.8 & 34.1 & 33.1 & 1.94 & \\
\hline Milk & $30.4^{k}$ & $32.1^{\mathrm{j}}$ & $27.7^{1}$ & $29.5^{\mathrm{k}}$ & 1.22 & $* * *$ \\
\hline Balance $^{\ddagger}$ & 3.0 & 6.0 & 10.6 & 12.0 & 2.46 & $\S$ \\
\hline
\end{tabular}

${ }_{j, k, l, m}$ Means within the same row and lactation stage with different superscripts differ $(P<0.05)$.

${ }^{\dagger}$ Treatments; $\mathrm{SP}=$ starch infused in abomasum; $\mathrm{GB}=$ glucose infused in blood; $\mathrm{AP}=$ amino acids infused in abomasum; $\mathrm{AB}=$ amino acids infused in blood.

${ }^{\ddagger}$ Calculated as: balance $=$ intake -milk-faeces-urine.

${ }^{\S}$ Approaching significance $(P<0.10)$. 
Table 4 Plasma metabolites and mammary extraction rates of plasma metabolites by dairy cattle infused with carbohydrates or amino acids into the abomasum or blood in late lactation

\begin{tabular}{|c|c|c|c|c|c|c|}
\hline & \multicolumn{6}{|c|}{ Treatments $^{\dagger}$} \\
\hline & $\mathrm{SP}$ & $\mathrm{GB}$ & AP & $A B$ & s.e. & Significance \\
\hline \multicolumn{7}{|l|}{ Glucose (mmol/l) } \\
\hline Arterial & $3.37^{\mathrm{k}}$ & $3.42^{k}$ & $3.37^{\mathrm{k}}$ & $3.56^{\mathrm{j}}$ & 0.066 & $* *$ \\
\hline Extraction (\%) & 24.2 & 25.8 & 25.2 & 25.4 & 0.83 & \\
\hline \multicolumn{7}{|l|}{$\mathrm{NEFA}^{\ddagger}(\mathrm{mmol} / \mathrm{l})$} \\
\hline Arterial & $0.185^{k}$ & $0.185^{k}$ & $0.198^{j}$ & $0.200^{j}$ & 0.005 & * \\
\hline Extraction (\%) & -14.7 & -13.7 & -9.3 & -8.4 & 3.67 & \\
\hline \multicolumn{7}{|l|}{ Hormones } \\
\hline Insulin (pmol/l) & $78.6^{\mathrm{k}}$ & $100.0^{\mathrm{k}}$ & $81.4^{\mathrm{k}}$ & $127.5^{j}$ & 11.1 & $* * *$ \\
\hline Glucagon (ng/ml) & 40.9 & 42.8 & 44.0 & 45.0 & 2.86 & \\
\hline IGF-1 (ng/ml) & $66.2^{\mathrm{k}}$ & $81.0^{\mathrm{j}}$ & $64.7^{\mathrm{k}}$ & $68.3^{\mathrm{k}}$ & 7.64 & $* * *$ \\
\hline $\mathrm{BGH}(\mathrm{ng} / \mathrm{ml})$ & 1.14 & 0.79 & 1.29 & 1.07 & 0.221 & $\S$ \\
\hline
\end{tabular}

${ }_{\mathrm{j}, \mathrm{k}, \mathrm{l}}$ Means within the same row and lactation stage with different superscripts differ $(P<0.05)$.

${ }^{\dagger}$ Treatments; $\mathrm{SP}=$ starch infused in abomasum; $\mathrm{GB}=$ glucose infused in blood; $\mathrm{AP}=$ amino acids infused in abomasum; $\mathrm{AB}=$ amino acids infused in blood

${ }^{\ddagger}$ Non esterified fatty acids.

${ }^{\S}$ Approaching significance $(P<0.10)$.

Table 5 Mean arterial plasma amino acid concentrations ( $\mu \mathrm{mol} / \mathrm{L}$ ) by dairy cattle infused with carbohydrates or amino acids into the abomasum or blood in late lactation

\begin{tabular}{|c|c|c|c|c|c|c|}
\hline & \multicolumn{6}{|c|}{ Treatments $^{\dagger}$} \\
\hline & SP & $\mathrm{GB}$ & $\mathrm{AP}$ & $A B$ & s.e. & Significance \\
\hline \multicolumn{7}{|l|}{ Essential } \\
\hline Arg & $96.5^{\mathrm{jk}}$ & $74.3^{\mathrm{kl}}$ & $106.6^{\mathrm{j}}$ & $69.3^{1}$ & 9.44 & * \\
\hline His & $36.8^{k}$ & $33.7^{\mathrm{k}}$ & $56.0^{\mathrm{j}}$ & $59.0^{\mathrm{j}}$ & 5.70 & $* * *$ \\
\hline Ile & $165^{\mathrm{j}}$ & $140^{k}$ & $180^{\mathrm{j}}$ & $172^{j}$ & 9.9 & $* *$ \\
\hline Leu & $130^{\prime}$ & $111^{\mathrm{m}}$ & $147^{\mathrm{k}}$ & $173^{j}$ & 8.6 & $* * *$ \\
\hline Lys & $107^{k}$ & $106^{\mathrm{k}}$ & $133^{j}$ & $118^{\mathrm{k}}$ & 9.6 & $* *$ \\
\hline Met & 24.9 & 25.1 & 23.4 & 22.6 & 1.47 & \\
\hline Phe & $53.7^{k}$ & $48.1^{k}$ & $52.1^{\mathrm{k}}$ & $60.4^{\mathrm{j}}$ & 2.59 & * \\
\hline Thr & 121 & 126 & 134 & 119 & 6.2 & $\S$ \\
\hline Val & $263^{k}$ & $222^{1}$ & $321^{\mathrm{j}}$ & $327^{\mathrm{j}}$ & 16.7 & $* * *$ \\
\hline \multicolumn{7}{|l|}{ Non-essential } \\
\hline Ala & $329^{\mathrm{j}}$ & $322^{\mathrm{jk}}$ & $304^{k}$ & $275^{\prime}$ & 14.5 & ** \\
\hline Asn & $68.8^{k}$ & $78.9^{j}$ & $79.3^{j}$ & $82.6^{\mathrm{j}}$ & 3.86 & ** \\
\hline Asp & 8.6 & 8.3 & 8.5 & 7.8 & 0.50 & \\
\hline Cys & 18.1 & 18.1 & 20.4 & 19.7 & 1.26 & \\
\hline Glu & 82.7 & 82.8 & 70.2 & 72.7 & 5.20 & $\S$ \\
\hline Gln & $359^{k}$ & $401^{j}$ & $339^{\mathrm{kl}}$ & $307^{\prime}$ & 17.2 & ** \\
\hline Gly & $394^{\mathrm{jk}}$ & $441^{j}$ & $399^{\mathrm{jk}}$ & $358^{k}$ & 20.2 & * \\
\hline Pro & 130 & 121 & 130 & 130 & 7.1 & \\
\hline Ser & $122^{\mathrm{k}}$ & $134^{\mathrm{j}}$ & $113^{\mathrm{kl}}$ & $111^{\prime}$ & 6.1 & $* * *$ \\
\hline Tyr & $54.3^{\mathrm{j}}$ & $48.0^{\mathrm{jk}}$ & $39.9^{k}$ & $41.5^{\mathrm{k}}$ & 3.30 & * \\
\hline Orn & $54.4^{k}$ & $51.0^{\mathrm{k}}$ & $66.4^{j}$ & $55.0^{k}$ & 4.88 & $* * *$ \\
\hline Cit & $90^{k}$ & $89^{k}$ & $104^{\mathrm{j}}$ & $96^{\mathrm{jk}}$ & 4.6 & * \\
\hline $\mathrm{EAA}^{\ddagger}$ & $998^{\mathrm{k}}$ & $887^{1}$ & $1152^{j}$ & $1120^{\mathrm{j}}$ & 49 & $* * *$ \\
\hline $\mathrm{NEAA}^{\ddagger}$ & $1566^{\mathrm{jk}}$ & $1656^{\mathrm{j}}$ & $1504^{k}$ & $1406^{1}$ & 52 & $* * *$ \\
\hline $\mathrm{BCAA}^{\ddagger}$ & $558^{k}$ & $474^{1}$ & $648^{j}$ & $672^{j}$ & 32 & $* * *$ \\
\hline $\mathrm{TAA}^{\ddagger}$ & 2564 & 2543 & 2656 & 2526 & 70 & \\
\hline Plasma urea $(\mathrm{mmol} / \mathrm{l})$ & $3.56^{\mathrm{m}}$ & $4.22^{\prime}$ & $5.07^{\mathrm{k}}$ & $5.50^{\mathrm{j}}$ & 0.14 & $* * *$ \\
\hline
\end{tabular}

$\mathrm{j}, \mathrm{k}, \mathrm{l}, \mathrm{m}$ Means within the same row and lactation stage with different superscripts differ $(P<0.05)$.

${ }^{\dagger}$ Treatments; $\mathrm{SP}=$ starch infused in abomasum; $\mathrm{GB}=$ glucose infused in blood; $\mathrm{AP}=$ amino acids infused in abomasum; $\mathrm{AB}=$ amino acids infused in blood.

${ }^{\ddagger}$ EAA = essential AA (Arg, His, lle, Leu, Lys, Met, Phe, Thr, and Val); NEAA = non-essential AA (Ala, Asn, Asp, Cys, Gln, Glu, Gly, Pro, Ser, and Tyr); BCAA = branched-chain AA (lle, Leu, and Val); TAA = EAA + NEAA.

${ }^{\S}$ Approaching significance $(P<0.10)$. 
Schei, Danfær, Mydland and Volden

Table 6 Mean extraction rate (\%) of plasma amino acids by the mammary gland by dairy cattle infused with carbohydrates or amino acids into the abomasum or blood in late lactation

\begin{tabular}{|c|c|c|c|c|c|c|}
\hline \multirow[b]{2}{*}{ Item } & \multicolumn{6}{|c|}{ Treatments $^{\dagger}$} \\
\hline & SP & GB & AP & $A B$ & s.e. & Significance \\
\hline \multicolumn{7}{|l|}{ Essential } \\
\hline Arg & 25.2 & 12.3 & 28.9 & 23.5 & 9.42 & \\
\hline His & $49.0^{\mathrm{j}}$ & $49.2^{\mathrm{j}}$ & $34.7^{\mathrm{jk}}$ & $22.2^{\mathrm{k}}$ & 6.07 & * \\
\hline lle & $31.3^{\mathrm{kl}}$ & $35.2^{\mathrm{jk}}$ & $27.7^{1}$ & $36.2^{\mathrm{j}}$ & 2.63 & ** \\
\hline Leu & $42.0^{\mathrm{kl}}$ & $49.5^{\mathrm{j}}$ & $40.1^{1}$ & $47.9^{\mathrm{jk}}$ & 3.00 & * \\
\hline Lys & 55.3 & 56.7 & 52.5 & 58.7 & 2.44 & \\
\hline Met & 55.4 & 54.3 & 63.2 & 67.6 & 6.07 & \\
\hline Phe & 44.4 & 44.7 & 51.6 & 42.6 & 3.31 & \\
\hline Thr & 28.1 & 29.7 & 25.7 & 28.9 & 3.27 & \\
\hline Val & 24.7 & 28.6 & 22.5 & 22.6 & 2.54 & \\
\hline \multicolumn{7}{|c|}{ Non-essential } \\
\hline Ala & 8.5 & 9.9 & 10.0 & -0.4 & 3.84 & \\
\hline Asn & 23.4 & 26.5 & 23.4 & 26.3 & 5.10 & \\
\hline Asp & 18.0 & 34.2 & 36.1 & 35.3 & 8.53 & \\
\hline Cys & 7.8 & 5.0 & 8.4 & 1.7 & 4.57 & \\
\hline Glu & 75.4 & 72.8 & 78.2 & 72.7 & 2.28 & \\
\hline Gln & 25.2 & 18.6 & 22.5 & 21.6 & 2.68 & \\
\hline Gly & 3.9 & 6.4 & 6.0 & 3.7 & 2.56 & \\
\hline Pro & 7.5 & 5.1 & 5.7 & -2.3 & 10.1 & \\
\hline Ser & 11.2 & 17.7 & 18.5 & 14.4 & 4.68 & \\
\hline Tyr & 42.9 & 36.7 & 57.8 & 59.4 & 6.02 & $\S$ \\
\hline Orn & 49.7 & 50.5 & 48.4 & 51.2 & 3.22 & \\
\hline Cit & 7.9 & 4.9 & 10.1 & 6.9 & 2.99 & \\
\hline $\mathrm{EAA}^{\ddagger}$ & 36.9 & 38.7 & 34.7 & 35.0 & 2.47 & \\
\hline $\mathrm{NEAA}^{\ddagger}$ & 17.1 & 16.2 & 17.7 & 14.5 & 2.24 & \\
\hline $\mathrm{BCAA}^{\ddagger}$ & $33.4^{\mathrm{k}}$ & $38.9^{j}$ & $29.9^{k}$ & $32.3^{\mathrm{k}}$ & 2.38 & * \\
\hline $\mathrm{TAA}^{\ddagger}$ & 24.9 & 23.9 & 25.0 & 23.6 & 2.23 & \\
\hline
\end{tabular}

$\mathrm{j}, \mathrm{k}, \mathrm{l}$ Means within the same row and lactation stage with different superscripts differ $(P<0.05)$.

${ }^{\dagger}$ Treatments; $\mathrm{SP}=$ starch infused in abomasum; $\mathrm{GB}=$ glucose infused in blood; $A P=$ amino acids infused in abomasum; $A B=$ amino acids infused in blood.

${ }^{\ddagger}$ EAA $=$ essential AA (Arg, His, lle, Leu, Lys, Met, Phe, Thr, and Val); NEAA = non-essential AA (Ala, Asn, Asp, Cys, Gln, Glu, Gly, Pro, Ser, and Tyr); $\mathrm{BCAA}=$ branched-chain AA (lle, Leu, and Val); TAA = EAA + NEAA.

${ }^{\S}$ Approaching significance $(P<0.10)$.

lactation and nutrient balances. Stage of lactation may have an effect on nutrient partitioning between milk and body tissues. However, it can be questioned whether the physiological status is more related to nutrient supply than stage of lactation per se (Kirkland and Gordon, 2001). In the present experiment, similar energy balances in early and late lactation make it possible to compare the nutritional effects on the animal performance. The response to absorbed protein is dependent on the energy status of the animal (Hanigan et al., 1998), where glucogenic AA might be oxidised or used as glucose precursors. For cows in negative energy balance higher AA availability will increase gluconeogenesis and thus lactose synthesis and thereby milk and protein yield, but have little effect on protein content as found in a Norwegian study (Schei et al., 2005). The negative energy balance in the present study might explain the general low milk protein content, since there is a positive correlation between energy intake and milk protein content (Coulon and Rémond, 1991; Rigout et al., 2003). However, for cows in positive energy balance, higher glucose availability has been shown to increase tissue energy balance and glucose oxidation, but have little effect on milk or protein yield (Reynolds et al., 1994). Total tract digestibility of $\mathrm{OM}$ and $\mathrm{CP}$ were 2.8 and $1.3 \%$ units higher in late lactation than in early lactation, respectively, which corresponds well to observations that increased feeding level decreases the digestibility of the same diet (Volden, 1999). Moreover, the percentage of urinary $\mathrm{N}$ excretion was 7.3 units higher in late lactation than in early lactation in spite of a lower feeding level, which also corresponds well to Volden (1999). Responses in milk yield and milk protein production were similar in early and late lactation. The higher AA availability due to $A A$ infusions increased urinary $\mathrm{N}$ excretion in early lactation and plasma urea in late lactation. Similar ME, and reversed urinary $\mathrm{N}$ and plasma urea in early and late lactation might indicate a different fate of the available $A A$ with only minor effect on milk production. Lower fat concentration in the $G B$ treatment in late lactation could be a dilution effect of increased yield resulting from an increase in glucose availability for lactose synthesis without concomitant increases in milk fat synthesis (Gaynor et al., 1995) which has been observed in other studies with glucose (Fisher et al., 1966; Hurtaud et al., 1998) or starch infusions (Reynolds et al., 2001). The responses in milk yield expressed in percentage were marginally higher in late than in early lactation (4.6 v. $6.6 \%)$. This is interesting since the infusion amounts in late lactation were lower than in early lactation. The $\mathrm{N}$ balance showed that the recovery of $\mathrm{N}$ in milk, urine and faeces were higher in late $(92.1 \%)$ than in early lactation $(88.3 \%)$, and therefore, the body protein retention was also higher in early lactation. This could be a result of a higher metabolic activity in the gastrointestinal tissues in early lactation as discussed in our corresponding paper (Schei et al., 2007). Using the same assumption as calculated by Raggio et al. (2004) as we did in the early lactation experiment (Schei et al., 2007) the loss of metabolic faecal nitrogen (MFN) with starch infusion was calculated to $5.6 \mathrm{~g} / \mathrm{kg}$ DMI. The corresponding figures with intravenous glucose infusion were $4.8 \mathrm{~g} / \mathrm{kg}$ DMl. Comparing these calculations with the corresponding values for early lactation (Schei et al., 2007), demonstrate that there is a higher loss of MFN in early than in late lactation. This indicates an increased protein turn-over and tissue growth in the gut. This could explain the higher retention in early lactation.

The $A B$ infusion increased plasma concentration of both glucose and insulin above that found for $G B$ infusion. These observations were not found in early lactation (Schei et al., 2007). This is difficult to explain, but Kim et al. (2000) also reported higher insulin concentration by intravenous NEAA compared with glucose infusion. Data on blood metabolite concentrations are often difficult to interpret in terms of nutrient fluxes, but the observed glucose 
concentrations on treatments $G B$ and $A B$ indicate that gluconeogenesis was reduced by glucose infusion more strongly in late than in early lactation. In both lactational stages, the plasma level of EAA was higher on treatment $A B$ than on treatment $G B$, whereas the opposite was the case for the concentration of NEAA. This suggest that gluconeogenesis from $A A$ was higher with $A B$ than with $G B$ infusion as NEAA is preferred to EAA as glucogenic substrates in cows (Black et al., 1968). On the other hand, the insulin concentration in late lactation was higher on treatment $A B$ than on treatment $G B$, and insulin is known to inhibit gluconeogenesis and to increase the uptake of glucose and AA in muscle cells (Sjaastad et al., 2003). Moreover, these results suggest that insulin concentration is hardly affected by nutrient supply in early lactation. The higher insulin level for $A B$ infusion in late lactation can be explained by the higher glucose concentration since insulin is more sensitive to glucose than to AA (Lemosquet et al., 1997). Individual AA like Arg and Leu may stimulate insulin more than other $A A$, and there is a synergistic effect on insulin release between glucose and AA (Lemosquet et al., 1997), which may have been important in our experiment. Abomasal AA infusion did not have the same effect on insulin as intravenous AA infusion, probably as a result of lower blood glucose level due to a lower gluconeogenesis. Higher arterial glucose concentrations with jugular compared with abomasal AA infusion was also observed by Thivierge et al. (2002) in cows 84 days in milk, but the arterial insulin concentrations did not differ. However, a higher insulin response may be expected with blood infusion of AA because the pancreas in this case would be exposed to the infused $A A$ before these are taken up by the liver. Infusion of glucose in the blood increased IGF-1 concentrations in both early (Schei et al., 2007) and late lactation, which is in line with other studies (Rigout et al., 2002; Lemosquet et al., 2004). This is related to the parallel increase in milk yield and milk protein yield (Lemosquet et al., 2004). Low circulating concentrations of IGF-1 in early lactation have been associated with negative energy balance (Spicer et al., 1990; Vicini et al., 1991) and with negative protein balance when energy balance is not already limiting (Ronge et al., 1988).

\section{Conclusions}

This study demonstrated that, compared with post-ruminal starch and AA infusion, intravenous glucose or AA infusion in late lactation had a positive effect on milk production to cows in negative energy balance. These results suggest that the mammary nutrient supply were lower when the substrates were given abomasaly. The lower nutrient supply is explained by a higher loss of MFN and use of these substrates in the intestinal tract or other tissue than the mammary gland. Higher urinary $\mathrm{N}$ losses by AA infusions in early than in late lactation indicate a higher $A A$ catabolism in early than in late lactation. In late lactation the milk response to glucose infusion was higher than in early lactation when compared with abomasal infusion of starch and AA. Compared with abomasal starch infusion, intravenous glucose infusion had minor effect on plasma AA concentration in early lactation, but in late lactation, the concentrations of EAA and BCAA were lower, because of a higher utilisation for milk protein production. Intravenous AA infusion increased plasma glucose and insulin above that of intravenous glucose infusion. The treatment effects on plasma insulin concentrations were higher in late than in early lactation, suggesting a higher sensitivity in late lactation even at similar negative energy balance. It is concluded that it is the nutrient supply and not the lactation stage per se that is important for the milk production response. The lactation stage is important for the response in plasma hormone concentrations.

\section{Acknowledgements}

The authors want to thank I. A. Boman all help, Dr. E. Prestløkken for help with blood sampling, Professor K. Hove for surgery on the cows, and the staff at Department of Animal and Aquacultural Sciences for their animal care and execution of the practical work. This work was funded by the Norwegian Research Council (grant no. 153019/110) and TINE Dairies BA.

\section{References}

Aikman PC, Reynolds CK, Humphries DJ, Beever DE and MacRae JC 2002. Milk protein response to abomasal or mesenteric vein essential amino acid infusion in lactating dairy cows. Journal of Dairy Science 85, 1079-1084.

Black AL, Egan AR, Anand RS and Chapman TE 1968. The role of amino acids in gluconeogenesis in lactating ruminants. In Isotope studies on nitrogen chain, pp. 247-261. International Atomic Energy Agency, Vienna.

Coulon JB and Rémond B 1991. Variations in milk output and milk protein content in response to the level of energy supply to the dairy cow: a review. Livestock Production Science 29, 31-47.

Fisher LJ and Elliot JM 1966. Effect of intravenous infusion of propionate or glucose on bovine milk composition. Journal of Dairy Science 49, 826.

Gaynor PJ, Waldo DR, Capuco AV, Erdman RA, Douglass LW and Teter BB 1995. Milk fat depression, the glycogenic theory, and trans-C18:1 fatty acids. Journal of Dairy Science 78, 2008-2015.

Hanigan MD, Cant JP, Weakley DC and Beckett JL 1998. An evaluation of postabsorptive protein and amino acid metabolism in the lactating dairy cow. Journal of Dairy Science 81, 3385-3401.

Hurtaud C, Rulquin H and Verite R 1998. Effects of graded duodenal infusions of glucose on yield and composition of milk from dairy cows. 1. Diets based on corn silage. Journal of Dairy Science 81, 3239-3247.

Kim C-H, Choung J-J and Chamberlain CG 2000. The effects of intravenous administration of amino acids and glucose on the milk production of dairy cows consuming diets based on grass silage. Grass and Forage Science 55, 173-180.

Kirkland RM and Gordon FJ 2001. The effects of milk yield and stage of lactation on the partitioning of nutrients in lactating dairy cows. Journal of Dairy Science 84, 233-240.

Lemosquet S, Rideau N and Rulquin H 1997. Insulin response to amino acid and glucose intravenous infusions in dairy cows: synergetic effect. Hormone and Metabolic Research 29, 556-560.

Lemosquet S, Rigout S, Bach A, Rulquin H and Blum JW 2004. Glucose metabolism in lactating cows in response to isoenergetic infusions of propionic acid or duodenal glucose. Journal of Dairy Science 87, 1767-1777.

Raggio G, Pacheco D, Berthiaume R, Lobley GE, Pellerin D, Allard G, Dubreuil P and Lapierre $H$ 2004. Effects of metabolizable protein on splanchnic flux of amino acids in lactating cows. Journal of Dairy Science 87, 3461-3472.

Reynolds CK, Cammell SB, Humphries DJ, Beever DE, Sutton JD and Newbold $J R$ 2001. Effect of postrumen starch infusion on milk production and energy metabolism in dairy cows. Journal of Dairy Science 84, 2250-2259. 
Reynolds CK, Harmon DL and Cecava MJ 1994. Absorption and delivery of nutrients for milk protein synthesis by portal-drained viscera. Journal of Dairy Science 77, 2787-2808.

Rigout S, Hurtaud C, Lemosquet S, Back A and Rulquin H 2003. Lactational effect of propionic acid and duodenal glucose in cows. Journal of Dairy Science 86, 243-253.

Rigout S, Lemosquet S, Van Eys JE and Blum JW 2002. Duodenal glucose increases glucose fluxes and lactose synthesis in grass silage-fed dairy cows. Journal of Dairy Science 85, 595-606.

Ronge H, Blum J, Clement C, Jans F, Leuenberger H and Binder H 1988. Somatomedin $\mathrm{C}$ in dairy cows related to energy and protein supply and to milk production. Animal Production 47, 165-183.

Schei I, Danfær A, Boman IA and Volden H 2007. Post-ruminal or intravenous infusions of carbohydrates or amino acids to dairy cows 1. Early lactation. Animal 1, 501-514.

Schei I, Volden H and Bævre L 2005. Effects of energy balance and metabolizable protein level on tissue mobilization and milk performance of dairy cows in early lactation. Livestock Production Science 95, 35-47.
Sjaastad ØV, Hove K and Sand 0 2003. Physiology of domestic animals, first edition. Scandinavian Veterinary Press, Oslo.

Spicer LJ, Tucker WB and Adams GD 1990. Insulin-like growth factor-1 in dairy cows: relationships among energy balance, body condition, ovarian activity and estrous behaviour. Journal of Dairy Science 73, 929-937.

Statistical Analysis Systems Institute 1999. Software release 8.2. SAS Institute Inc., Cary, NC.

Thivierge MC, Bernier JF, Dubreuil P and Lapierre H 2002. The effect of jugular or abomasal infusion of amino acids on milk yield in lactating cows fed a protein deficient diet. Reproduction Nutrition Development 42, 1-13.

Vicini JL, Buonomo FC, Veenhuizen JJ, Miller MA, Clemmons DR and Collier RJ 1991. Nutrient balance and stage of lactation affect responses of insulin, insulinlike growth factor I and II, and insulin-like growth factor-binding protein 2 to somatotropin administration in dairy cows. Journal of Nutrition 121, 1656-1664.

Volden H 1999. Effects of level of feeding and ruminally undegraded protein on ruminal bacterial protein synthesis, escape of dietary protein, intestinal amino acid profile, and performance of dairy cows. Journal of Animal Science 77, 1905-1918. 